Review

\title{
Land-Use Threats and Protected Areas: A Scenario-Based, Landscape Level Approach
}

\author{
Tamara S. Wilson *, Benjamin M. Sleeter, Rachel R. Sleeter and Christopher E. Soulard \\ U.S. Geological Survey, 345 Middlefield Road MS-531, Menlo Park, CA 94025, USA; \\ E-Mails: bsleeter@usgs.gov (B.M.S.); rsleeter@usgs.gov (R.R.S.); csoulard@usgs.gov (C.E.S.) \\ * Author to whom correspondence should be addressed; E-Mail: tswilson@usgs.gov; \\ Tel.: +1-650-329-4247.
}

Received: 21 January 2014; in revised form: 21 March 2014 / Accepted: 28 March 2014 /

Published: 8 April 2014

\begin{abstract}
Anthropogenic land use will likely present a greater challenge to biodiversity than climate change this century in the Pacific Northwest, USA. Even if species are equipped with the adaptive capacity to migrate in the face of a changing climate, they will likely encounter a human-dominated landscape as a major dispersal obstacle. Our goal was to identify, at the ecoregion-level, protected areas in close proximity to lands with a higher likelihood of future land-use conversion. Using a state-and-transition simulation model, we modeled spatially explicit $\left(1 \mathrm{~km}^{2}\right)$ land use from 2000 to 2100 under seven alternative land-use and emission scenarios for ecoregions in the Pacific Northwest. We analyzed scenario-based land-use conversion threats from logging, agriculture, and development near existing protected areas. A conversion threat index (CTI) was created to identify ecoregions with highest projected land-use conversion potential within closest proximity to existing protected areas. Our analysis indicated nearly $22 \%$ of land area in the Coast Range, over $16 \%$ of land area in the Puget Lowland, and nearly $11 \%$ of the Cascades had very high CTI values. Broader regional-scale land-use change is projected to impact nearly $40 \%$ of the Coast Range, $30 \%$ of the Puget Lowland, and $24 \%$ of the Cascades (i.e., two highest CTI classes). A landscape level, scenario-based approach to modeling future land use helps identify ecoregions with existing protected areas at greater risk from regional land-use threats and can help prioritize future conservation efforts.
\end{abstract}

Keywords: land use; land cover; protected areas; scenarios; state-and-transition models; IPCC; conversion threat; Pacific Northwest 


\section{Introduction}

Anthropogenic land use will likely present a greater challenge to biodiversity than climate change this century [1]. In the last 300 years alone, more than half of the earth's land surface has been transformed by human activity [2,3], driving widespread habitat losses [4-6] and ecosystem alteration [7]. Changes in land use and land cover (LULC) have been linked to species extinction [8], changes in species diversity [9], declines in water [10] and air quality [11,12], increases in carbon dioxide emissions [13], and climate change at regional and global scales [14-17]. The magnitude and impact of human land use on earth's environment will only increase this century, given population projections and associated demand for food, fiber, and energy. Despite existing environmental protections and management strategies, increased human land use is likely to further isolate protected areas, inhibiting landscape and biological connectivity [18] and diminishing habitat quality. This is especially the case in the mountainous western United States (hereafter termed the Pacific Northwest), where competition between human land use and land conservation is high [19].

The setting aside of protected areas is intended to preserve areas of considerable ecological, spiritual, or aesthetic value and safeguard biodiversity [20]. However, protected areas do not operate in isolation of regional ecological flows and processes influenced by non-local human activity [21]. Regional land-use pressures outside of protected areas boundaries often have far-reaching, trans-boundary impacts on ecological processes and can threaten biodiversity within protected area boundaries [22]. The selection and establishment of additional protected areas can be significantly challenged by regional land use [23-26], as potential corridors linking wild lands continually shrink [27]. Even if species are equipped with the adaptive capacity to migrate in the face of a changing climate, they will likely encounter a human dominated landscape as a major dispersal obstacle [28].

Research on land-use threats to protected areas has focused on single land use, such as how road networks [29], residential encroachment [27,30], and forest clearing [31] impact protected areas. Additionally the impacts of agriculture [32] and logging [33,34] on regional habitat and biodiversity has been examined. These studies provide useful insight into land-use specific impacts but fall short in representing the land-use threat mosaic at the landscape level. Individual species as well as community assemblages have varying response mechanisms to cope with land-use pressures, depending on land-use type. To address this, Ricketts and Imhoff [35] examined both urbanization and agricultural threats to biodiversity to prioritize conservation efforts in ecoregions of the United States. Incorporating multiple land-use threats into biodiversity assessments provides a more robust, landscape level view of vulnerabilities to land-use change [36].

With diminishing resources as well as diminishing time to enact effective management strategies, more rapid, landscape level analyses are needed to assess multiple land-use threats to biodiversity in areas adjacent to protected land [37]. While species level analysis of land-use impact clearly yield the most detailed information, they are often costly, difficult to implement, and challenging to integrate into the greater ecological framework. The development of landscape level scenarios of future land use can help quickly identify areas with higher probability of land-use conversion and subsequent losses of both habitat and potential ecosystem reserves [38]. The exploration of spatially explicit land-use conversion scenarios is useful in prioritizing protected areas at greater risk from regional land-change scenarios [36,39] and inform land use and regional conservation planning decisions. 
Land-use conversion potential is a key factor in the selection process for new protected lands, helping identify protected land vulnerability [40] and guide management strategies [36,41]. Research on the economics of private land conservation highlights the importance of potential future land conversion on site selection and for optimizing biological benefits of existing conservation areas [42]. In areas with a high likelihood of land conversion there is a positive correlation with cost of land protection [42]. As a consequence, identifying protected areas surrounded by land with a higher likelihood of future conversion can help prioritize future conservation efforts and resources [36,38]. We utilized a state-and-transition simulation model (STSM) to generate annual, spatially explicit LULC change scenarios at $1 \mathrm{~km}^{2}$ across a range of land-use types to the year 2100. We analyzed scenario-based land-use conversion threats from logging, agriculture, and development near existing protected areas in the Pacific Northwest. A conversion threat index (CTI) was then developed based on measures of scenario agreement on land-use change and proximity of land-use change to protected area boundaries.

\subsection{Land Use and Land Cover Scenarios}

Given the broad range of future uncertainties, LULC projections are useful tools allowing land managers to visualize alternative landscape futures, to optimize management practices and improve planning [43-46]. Scenarios represent plausible outcomes based on scenario assumptions and/or scenario data trajectories. Research using spatially explicit LULC scenarios has analyzed the impacts of land conversion on biodiversity [47], hydrology [48], carbon fluxes [49], and climate change [15]. Scenario modeling has also identified land use as the leading driver of change in global biodiversity by the year 2100 [4]. Scenario-based LULC projections have recently been published for various regions in the U.S. [25,50-55]. We present STSM generated LULC projections at $1 \mathrm{~km}^{2}$ based on seven alternative future scenarios modeled to 2100 for the Pacific Northwest. Our objective was to identify ecoregions with protected areas most threatened by future regional land-use change.

The Intergovernmental Panel on Climate Change's (IPCC) Special Report on Emissions Scenarios (SRES) [43] included information on land use reported for four macro-scale world regions. The SRES scenarios have been widely used by the global change community to understand future environmental conditions resulting from climate change [45,56-59]. These scenarios represent a broad range of socio-economic futures and include assumptions of future population, economic development, technological innovation, and changes in energy resources and use-the major driving forces of greenhouse-gas emissions. These course-scale data were downscaled to hierarchically nested ecoregions of the conterminous United States to the year 2100 for the A1B, A1, B1, and B2 scenarios [60]. The main characteristics of the SRES scenarios are summarized in (Figure 1). Changes in LULC "demand" (i.e., the amount of land projected to undergo a change in land use) were projected at 5-year intervals from 2000 to 2100 for 15 LULC classes, including 10 natural land-cover classes (water, barren, grassland, shrubland, deciduous forest, evergreen forest, mixed forest, herbaceous wetland, woody wetland, ice/snow) and five land-use classes (developed, mining, logging, agriculture, hay/pasture) [60]. The developed land-use class encompassed areas of intensive use with much of the land covered with structures (e.g., high density residential, commercial, industrial, transportation, confined livestock operations), or less intensive uses where the land cover matrix includes both vegetation and structures 
(e.g., low density residential, recreational facilities, cemeteries, etc.), including any land functionally attached to the urban or built-up activity [60].

Figure 1. Characteristics of the four scenarios based on major driving forces behind the Intergovernmental Panel on Climate Change's Special Report on Emission Scenarios [60].

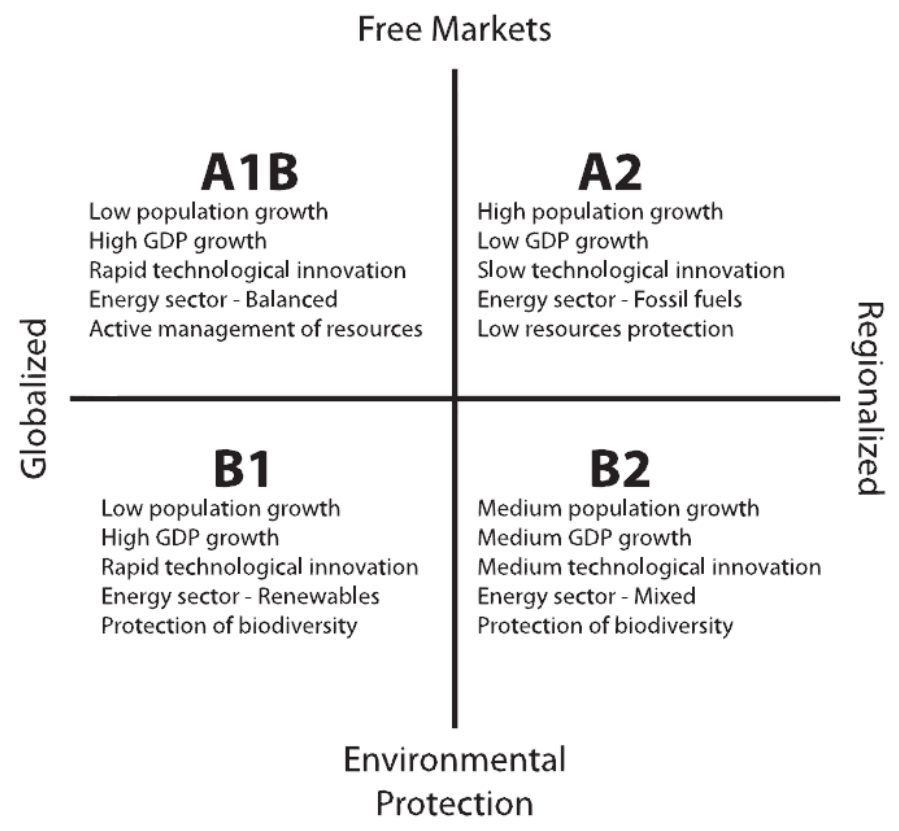

Additional scenarios have been developed utilizing estimates of LULC change from the USGS Land Cover Trends ("Trends") project data [61]. The Trends data include estimates of LULC change in each of the 84 ecoregions [62] of the conterminous United States for four temporal periods spanning 1973-1980, 1980-1986, 1986-1992, and 1992-2000. We developed three additional scenarios based on the historical Trends observations. These included: (1) a "business as usual" scenario based on change estimates for the 1992-2000 Trends period; (2) a "random" scenario, which randomly selects a conversion rate between any of the four possible Trends time intervals; and (3) a "historic case" scenario based on the 1986 to 1992 Trends LULC change estimates. The 86-92 Trends period was marked by the high rates of historical timber harvest in the Pacific Northwest, compared to the 92-00 Trends period [63]. The 86-92 and 92-00 Trends change estimates captured the varying forest harvest rates and represent a high and low harvest scenario, respectively. Each Trends scenario was projected out to 2100 following historic LULC change trajectories defined in the scenario nomenclature.

\section{Study Region}

The Pacific Northwest is comprised of the eight Level III ecoregions: (1) Coast Range; (2) Puget Lowland; (3) North Cascades; (4) Cascades; (5) Eastern Cascades Slopes and Foothills (hereafter East Cascades); (6) Willamette Valley; (7) Klamath Mountains; and (8) Sierra Nevada Mountains (hereafter Sierra Nevada) (Figure 2), spanning approximately $319,583 \mathrm{~km}^{2}$. Dominant LULC classes include forest (64.4\%), grassland/shrubland (21.3\%), agriculture (4.4\%), and development (4.4\%) [19] (Figure 3A). Ecoregions are useful units of analysis as they represent semi-continuous regions with common biotic, abiotic, and aquatic characteristics, as well as resource capacity and land-use potential [64]. They are 
defined by fine scale patterns of ecological organization and shaped by local climate and geography, resulting in unique species assemblages. Ecoregions have proven useful for observing and synthesizing information on LULC change [64,65] and for landscape level analysis of biodiversity [9,35,66]. Level III ecoregions [62] were used in both the downscaling of the SRES data and in deriving LULC change estimates in the Trends data and serve as the geographic framework for future scenario projections.

Figure 2. (A) The Pacific Northwest and the Level III ecoregion boundaries. Basemap satellite data copyright ${ }^{\circ}$ ESRI, DeLorme, NAVTEQ, TomTom; (B) Inset map of the Level III ecoregion extent; (C) Location map with ecoregions in yellow.

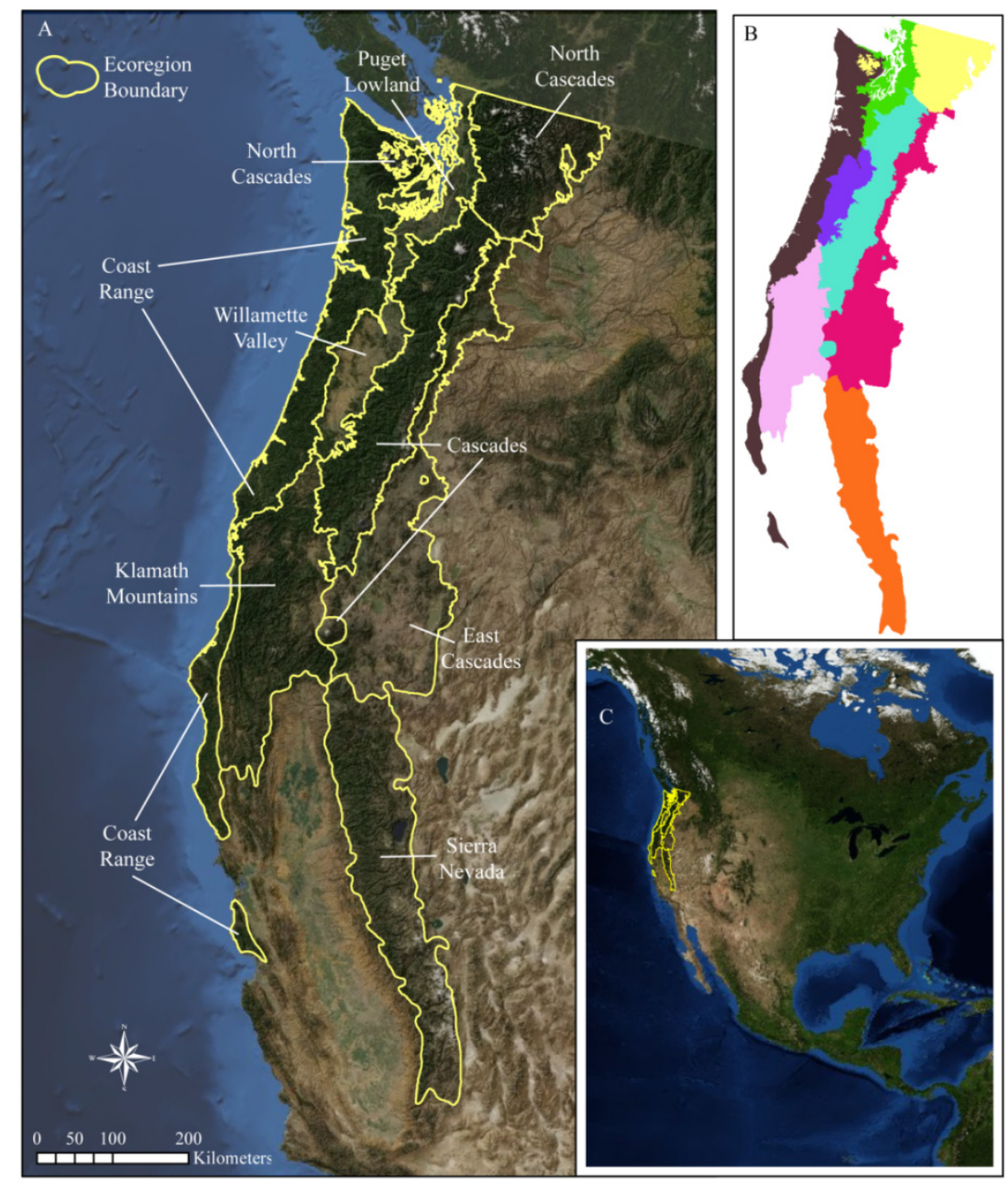

The Pacific Northwest region has a broad range of land uses and exhibited some of the highest historical rates of LULC change estimated between 1973 and 2000 [30,63]. Trends ranked the Puget Lowland, Coast Range, and Willamette Valley among the highest changing ecoregions in the western U.S. [19]. The percent area of each ecoregion that changed at least one time between the 1973 to 2000 (i.e., footprint of change) in the Trends study period, was 28.0\% (Puget Lowland), 25.5\% (Coast Range), 24.6\% (Cascades), 14.5\% (Willamette Valley), 12.1\% (East Cascades), 10.5\% (North Cascades), 8.5\% (Klamath Mountains), and 5.0\% (Sierra Nevada) [19]. Population growth rates were almost twice as high as the national average with regional population nearly doubling since 1970 [67]. As a result, national housing growth rates during 1940 to 2000 within $50 \mathrm{~km}^{2}$ of wilderness areas, national parks, and national forests were highest in the Pacific Northwest [30]. 
Figure 3. (A) The Pacific Northwest land use and land cover (LULC) in the year 2000 based on the harmonized land cover dataset described in Section 3.3. Basemap satellite data copyright ${ }^{\circledR}$ ESRI, DeLorme, NAVTEQ, TomTom; (B) Protected areas in the Pacific Northwest with GAP Status 1 (dark green) and 2 (light green).

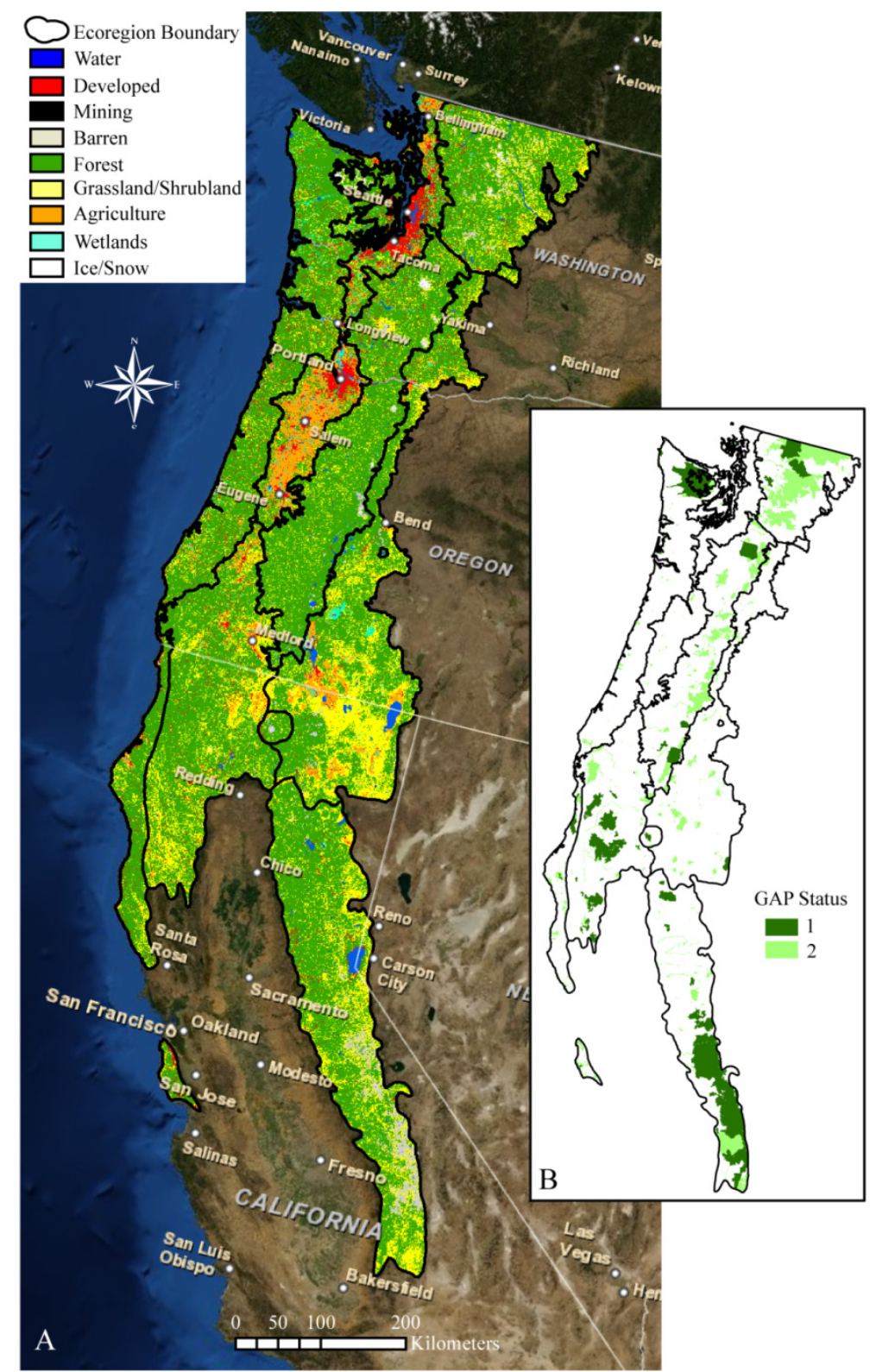

\section{Methods}

\subsection{Protected Areas}

Our LULC modeling approach utilized the Protected Areas Database of the United States (PAD-US) produced by the USGS National Gap Analysis Program (GAP) [68]. Areas categorized as GAP Status 1 or 2 (hereafter termed protected areas; Figure 3B) were not allowed to undergo land-use conversion in any scenario and were spatially constrained using the spatial multipliers discussed in Section 3.4. GAP Status 1 areas are defined as having permanent protection from conversion of natural land cover and a mandated management plan in operation to maintain a natural state within which 
disturbance events (of natural type, frequency, intensity, and legacy) are allowed to proceed without interference or are mimicked through management. Areas with GAP Status 2 have permanent protection from conversion of natural land cover and a mandated management plan in operation to maintain a primarily natural state, but which may receive uses or management practices that degrade the quality of existing natural communities, including suppression of natural disturbance [68]. We assumed existing protected areas remained constant through 2100.

\subsection{State-and-Transition Modeling}

State-and-transition simulation models (STSMs) have been widely used to simulate landscape level vegetation changes over time [69]. STSMs are stochastic, empirical simulation models that use an adapted Markov chain approach to predict how variables transition between different states over a specified timeframe [70]. An STSM first divides a given landscape into a set of simulation cells with an assigned initial state class (e.g., vegetation type, LULC, successional stage, pixel age). The model then predicts how each individual cell changes between state classes over time. The latest generation of STSMs track age-structure, allow target setting for specific transitions, enable varying transition rates over time, and can include triggering transitions based on historic events [71]. STSMs have two mechanisms for representing spatial variability by: (1) dividing a landscape into defined spatial strata based on landscape similarities, administrative boundaries, or common drivers of change or (2) using a spatially explicit STSM where transition events (i.e., fire, forest harvest, non-native species invasions) can be modeled to spread across the landscape [70].

STSMs have been used to address management questions across a broad range of landscape types and spatial scales $[69,72]$. Any number of mitigation strategies, management objectives, treatment options, or preferred futures can be simulated. In the Pacific Northwest, STSMs are being used to simulate changes in forest structure and composition in efforts to revise forest plans in both Washington and Oregon states [71]. They modeled natural and human-induced forest disturbance as well as various combinations of forest treatment options (i.e., prescribed burns, thinning) and the associated changes in forest structure [71]. This strategy enabled the exploration of different potential management techniques and resulting outcomes based on empirical knowledge. STSMs are ideally suited for linking experimental/ observational data representative of a given landscape to a broader scale and evaluating landscape level response to management activities [73].

The STSM software ST-Sim was used to model all future LULC change scenarios [74]. In order to facilitate analysis between the scenario datasets described in Section 1.1 and the harmonized dataset [75] described in Section 3.3, we collapsed the original 15 LULC classes into nine Anderson Level I LULC classes (water, developed, barren, mining, grassland/shrubland, forest, agriculture, wetlands, and forest harvest) [76]. The deciduous, evergreen, and mixed forest classes were aggregated into a single forest class. The agriculture and hay/pasture classes combined into an agriculture class. The grassland and shrubland classes were grouped into a single grassland/shrubland class. We examined all transitions out of natural land cover and into land use (i.e., developed, agriculture, and forest harvest) as well as transitions between land uses (i.e., from agriculture to developed). Described herein is the method for initiating and parameterizing our spatial model run. 


\subsection{Model Initiation}

Initial conditions were first defined by supplying a base strata file of Level III ecoregions of the Pacific Northwest [62]. For our initial state classes, we utilized a newly developed, harmonized $1 \mathrm{~km}^{2}$ LULC map product for the year 2000 as our initial state class input [75]. The harmonized LULC state class map was created from the merging and validation of the different 30-meter resolution datasets listed in Table 1 [77-85]. These datasets were harmonized using a pixel-based data fusion process [86]. Nomenclature differences were reconciled through limited aggregation of classes. The resulting product used the Anderson Level 1 classification scheme [76]. The harmonization process identified pixels remaining unchanged across datasets, relying on convergence of evidence. Classification uncertainty was checked against reference imagery and validation datasets. Areas with LULC uncertainty between datasets were edited to reflect majority classification agreement. The $30 \mathrm{~m}$ harmonized LULC map was then resampled to $1 \mathrm{~km}^{2}$ to serve as the best available initial state class map.

Table 1. National spatial datasets used in the harmonized land use and land cover (LULC) map product.

\begin{tabular}{|c|c|c|c|}
\hline Dataset & Date & Description & Reference \\
\hline \multirow{3}{*}{$\begin{array}{l}\text { National Land Cover Dataset } \\
\text { (NLCD) }\end{array}$} & 1992 & \multirow{3}{*}{ Land cover databases } & [77] \\
\hline & 2001 & & {$[78]$} \\
\hline & 2006 & & [79] \\
\hline NLCD Retro Product & 1992,2001 & $\begin{array}{c}\text { 1992-2001 retrofitted land cover change } \\
\text { database }\end{array}$ & {$[80]$} \\
\hline $\begin{array}{l}\text { LANDFIRE's Vegetation } \\
\text { Change Tracker (VCT) }\end{array}$ & $1984-2010$ & Annual forest disturbance & [81] \\
\hline $\begin{array}{l}\text { Web-enabled Landsat Data } \\
\text { (WELD) }\end{array}$ & $2006-2011$ & Forest declines over 5-year period & {$[82]$} \\
\hline Cropland Data Layer (CDL) & 2010,2011 & Crop specific estimates of crop acreage & {$[83]$} \\
\hline $\begin{array}{l}\text { Monitoring Trends in Burn } \\
\text { Severity (MTBS) }\end{array}$ & $1984-2010$ & Annual burn severity and wildfire perimeters & {$[84]$} \\
\hline Forest Cover Types & 1991 & $\begin{array}{l}25 \text { classes of forest cover as well as water and } \\
\text { non-forested lands }\end{array}$ & {$[85]$} \\
\hline
\end{tabular}

An initial 2000 forest stand age map was generated from LANDFIRE Vegetation Change Tracker (VCT) [81] and data from Pan et al. [87]. The spatially explicit data from Pan et al. set forest age for the year 2006 for all forested areas in the U.S. and Canada. These data were recalculated to represent forest age at the year 2000, the start of our scenario simulations. Forested pixels younger than six years of age in the original 2006 data (indicating a stand-replacing event occurred between 2000 and 2006), were assigned a random age based on an ecoregion's stand age distribution. VCT data for the period 1984-2000 were resampled to $1 \mathrm{~km}^{2}$ resolution and "burned" into the stand age map. Stand age was tracked through each modeled time step and reset to "0" whenever a forested pixel was harvested. A 45-year minimum harvest age was applied [50]. We set our model to run over 100 time steps (year 2000-2100) at a single Monte Carlo iteration, due to current computing limitations and output data processing requirements. 


\subsection{Model Parameterization}

Tabular data for each of the seven scenarios described in Section 1.1 were imported into ST-Sim and set as area targets for projected LULC change over the modeled period. In order to spatially constrain allowable land-use transitions, ST-Sim employs a spatial multiplier technique. Spatial multipliers identify pixels at higher or lower probability of conversions between specified LULC types. We developed a set of spatial multipliers to help guide placement of land-use related conversions (Table 2) $[68,75,81,88,89]$. Majority filters were applied to each individual state class to reduce the amount of single pixels or "salt and pepper" effect on the landscape. A focal filter replaced the center cell with the majority value of the eight surrounding cells. This process preserved larger patches of the same LULC state class, an important pre-cursor for the subsequent "distance to" calculations. All of the "distance to" parameters included in Table 2 were calculated using Euclidean distance. Values in all datasets were rescaled to values between 0 and 1 to generate probability raster maps. GAP Status 1 and 2 lands (i.e., protected areas) [68] were restricted from conversion in each spatial multiplier and applied a 0 probability for conversion. Transitions without a defined spatial multiplier were randomly selected by the model. The various components used for the ST-Sim model initiation are shown in Figure 4.

Table 2. Spatial multipliers developed to spatially constrain land-use conversions.

\begin{tabular}{|c|c|c|}
\hline Spatial Multiplier & $\begin{array}{l}\text { Description } \\
\end{array}$ & Datasets and Reference \\
\hline Forest Harvest & $\begin{array}{l}\text { Sets parameters for allowable forest harvest } \\
\text { transition based on distance to historic harvest } \\
\text { (1984-2009 cumulative harvest from VCT), a } \\
\text { majority filter of } 8 \text { pixels, and conversions on } \\
\text { protected lands were restricted (GAP } 1 \& 2 \text { ). }\end{array}$ & $\begin{array}{l}\text { VCT [81] } \\
\text { PAD-US [68] }\end{array}$ \\
\hline $\begin{array}{l}\text { Agriculture to } \\
\text { Grassland/Shrubland }\end{array}$ & $\begin{array}{l}\text { Sets probabilities of conversion based on distance to } \\
\text { existing grassland/shrublands, low crop capability, a } \\
\text { majority filter of } 8 \text { pixels, and restricts conversion } \\
\text { on protected lands (GAP } 1 \text { \& } 2 \text { ) }\end{array}$ & $\begin{array}{l}\text { Harmonized LULC [75] } \\
\text { Crop Capability [88] } \\
\text { PAD-US [68] }\end{array}$ \\
\hline To Developed & $\begin{array}{l}\text { Sets probabilities of conversion into developed land } \\
\text { with highest probability occurring on land closest to } \\
\text { existing, high density development }\left(>80 \text { people } / \mathrm{km}^{2}\right) \text {. } \\
\text { Distance to development was calculated and pixels } \\
>20 \mathrm{~km}^{2} \text { away from existing development were } \\
\text { excluded. A majority filter of } 8 \text { pixels was also } \\
\text { applied. Distance to development and distance to } \\
\text { high population density were multiplied to produce } \\
\text { final probability map. Conversions not allowed on } \\
\text { protected lands (GAP Status } 1 \& 2 \text { ) }\end{array}$ & $\begin{array}{l}\text { Harmonized LULC [75] } \\
\text { Population Density [89] } \\
\text { PAD-US [68] }\end{array}$ \\
\hline To Agriculture & $\begin{array}{l}\text { Sets probabilities of conversion into agriculture } \\
\text { based on distance to existing agriculture and crop } \\
\text { capability. Restricts conversion on protected lands } \\
\text { (GAP } 1 \text { \& 2). }\end{array}$ & $\begin{array}{l}\text { Harmonized LULC [75] } \\
\text { PAD-US [68] }\end{array}$ \\
\hline
\end{tabular}


Figure 4. Conceptual diagram of the major components used in the ST-Sim modeling framework and model output.

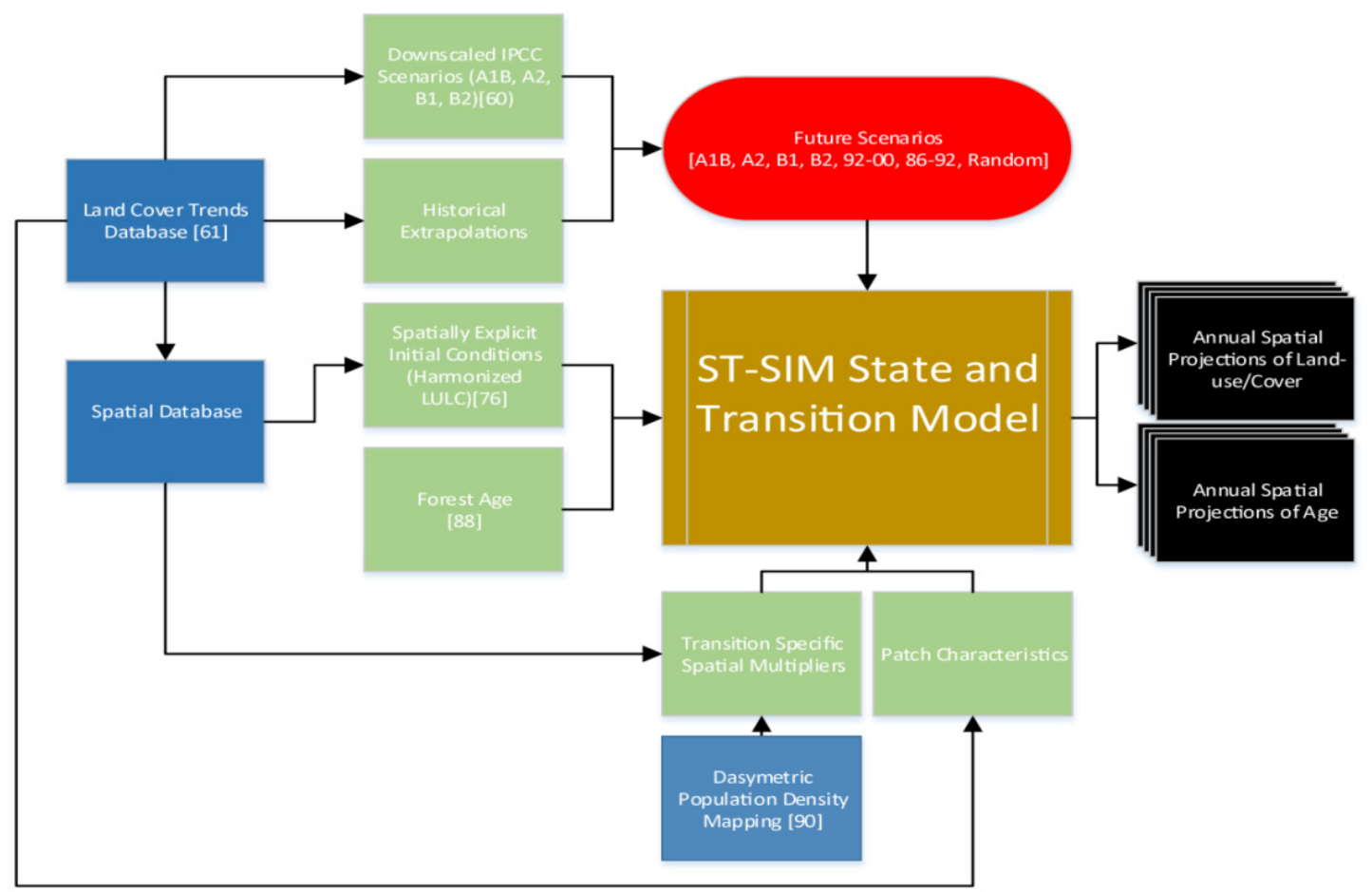

\subsection{Processing Model Output}

Spatial model output was exported from ST-Sim for each scenario model run including (1) annual state class output and (2) annual transition maps ( $>29,000$ raster files). All transition group conversion files were catalogued by conversion type and scenario for the major land-use changes (i.e., conversions to agriculture, development, and forest harvest). Each conversion type had a unique transition group value with all non-converting pixels coded as 0 . Cell statistics were applied to combine all non-zero pixels which underwent a given land-use conversion during the model period for each scenario. Resulting output provides a footprint and sum of each given conversion, accounting for total area converted and multiple conversions.

For total conversions into development, the initial state class LULC raster file was reclassified as binary, where all 1's represent existing development at model initiation. For each LULC scenario, modeled output at the year 2100 was reclassified, where all developed pixels were classified as 2 and all other classes set to 0 . The year 2100 was subtracted from the year 2000. All remaining pixels classified as 1 represented newly developed pixels over the model period run. Since transitions into developed lands were uni-directional, a simple analysis at the ending timestep captures all conversions to development over the modeled period. The process described above was also conducted on all transitions to development from agriculture, forest, and grassland/shrubland.

Total forest harvest was calculated by reclassifying each annual forest harvest file as binary. These were then summed by scenario using cell statistics. The resulting raster output for each scenario contained values $1-3$, representing the number of times a given pixel was harvested over the scenario's study period. Values of 1 represented the overall areal extent of forest harvest, with values of 3 being the maximum number of times a pixel was projected to be harvested, given the 45 year minimum 
harvest age set in the model. We then calculated potential harvest intensity, summing forest harvest across all seven scenarios, resulting in values ranging from 1 to 18 . Values of 18 represented pixels where all seven scenarios agreed a forested pixel would be harvested and most scenarios agreed two or three harvest cycles would occur. All conversions into agriculture from grassland, forest, and wetlands were calculated by recoding all transition groups as binary and applying a sum cell statistics function. This results in total agriculture conversions from each initial state class. We did not disentangle multiple conversions into and out of agriculture. We assumed a conversion into agriculture even if cyclic in nature was a significant enough departure from starting natural vegetation state (i.e., habitat condition) to assume fairly permanent alteration.

\subsection{Land Conversion Potential and Conversion Threat Mapping}

To calculate land conversion potential, all transition group files were reclassified as binary and summed by maximum value over the model period for all seven scenarios. When combined, these values represented areas where $\geq 1$ scenarios agreed a given change will occur. In the case of forest harvest, some pixels experienced two or three forest harvest events during the 100 year period. Those values were summed and rescaled to seven classes using natural breaks to facilitate analysis between land-use types in the method described below.

Conversion potential reveals the degree to which the seven scenarios were in agreement on the spatial location of future LULC change. Conversion potential (CP) was mapped for all major land-use conversion types as follows:

$$
\mathrm{CP} c_{2000-2100}^{P}=\sum \operatorname{LULC} c \Delta_{y 1 \ldots y \mathrm{n}}^{P s^{1 \ldots n}}
$$

where $\mathrm{CP}^{P}$ is the conversion potential $(\mathrm{CP})$ projected $(P)$ for each cell $(c)$ over the model period 2000-2100 and LULC $c \Delta_{y 1 \ldots y n}^{P s^{\#}}$ is the projected land use and land cover (LULC) change in a cell for a given scenario $\left(s^{1 \ldots n}\right)$ for each year $(y)$ over the modeled period. A value of 7 indicates all scenarios projected a change in LULC for that location, while a value of 0 indicates that none of the scenarios projected a change.

To create our conversion threat index (CTI), we first calculated total onshore protected area extent and amount per ecoregion. Protected areas boundaries were grouped together into continuous areas by dissolving common boundaries to facilitate "distance to" analyses described below. We converted all GIS data to raster format to maintain spatial accuracy.

We then analyzed the $\mathrm{CP}$ at a range of distances to protected areas in the Pacific Northwest. We calculated Euclidean "distance to" (DT) measurements at 5, 10, 20, 40, and $50 \mathrm{~km}$ buffer distances around each protected area and reclassified these distance values as 5, 4, 3, 2, and 1 respectively. A DT value of 5 represents pixels within $5 \mathrm{~km}$ of a protected area and a DT value of 1 represents pixels between 40.1 and $50 \mathrm{~km}$ away. Similar work has calculated the amount of housing and development at varying incremental distances within $50 \mathrm{~km}$ of a protected area [30,90]. A broad range of distances was selected to capture a range of threats. Land use within $5 \mathrm{~km}$ of a protected area has a more direct impact on protected areas than land use at greater distances which can contribute to invasive species spread, serve as a barrier to dispersal within connective corridors, and further isolate protected areas [30]. A conversion threat index $(\mathrm{CTI})$ was then calculated for each cell as: 


$$
\mathrm{CTI} c=\mathrm{CP}_{2000-2100}^{P} \times \mathrm{DT}^{\mathrm{PA}}
$$

where $\mathrm{CP} c_{2000-2100}^{P}$ represents the cell's conversion potential over the model period and $\mathrm{DT}^{\mathrm{PA}}$ represents distance to protected area boundary. Resulting CTI values (from 1 to 35) were classified as follows: values $1-6, \mathrm{CTI}=$ not classified (i.e., these values represent minimal scenario agreement at greater distances from a protected area boundary); values 7-12, CTI = low; values 13-20, CTI = medium; values $21-25, \mathrm{CTI}=\mathrm{high}$; and values $26-35, \mathrm{CTI}=$ very high. High CTI values correspond to the high conversion potential in closest proximity to protected areas.

\section{Results}

\subsection{Changes in Development and Agricultural Land Use over the Modeled Period}

Results of land-use change across the seven scenarios exemplified scenario divergence in the rates and types of land-use change. Increases in development and agricultural land uses were seen across all scenarios, but were highest in the regional/free market A2 scenario, resulting in $17,569 \mathrm{~km}^{2}$ of forest cleared (Table 3).

Table 3. Total projected Pacific Northwest land area conversions $\left(\mathrm{km}^{2}\right)$ between 2000 and 2100 to developed and agriculture for each scenario.

\begin{tabular}{|c|c|c|c|c|c|c|c|c|}
\hline \multirow[b]{2}{*}{ To Class } & \multirow[b]{2}{*}{ From Class } & \multicolumn{7}{|c|}{ LULC Scenarios } \\
\hline & & A1B & A2 & B1 & B2 & $\begin{array}{c}\text { Trends } \\
86-92 \\
\end{array}$ & $\begin{array}{c}\text { Trends } \\
92-00 \\
\end{array}$ & $\begin{array}{c}\text { Trends } \\
\text { Random }\end{array}$ \\
\hline \multirow{5}{*}{ Developed } & Forest & 5745 & 8104 & 3360 & 2051 & 6600 & 6500 & 5565 \\
\hline & Agriculutre & 2810 & 3907 & 2086 & 1140 & 4412 & 2902 & 2900 \\
\hline & Grassland/Shrubland & 950 & 978 & 943 & 741 & 800 & 900 & 760 \\
\hline & All Other & 796 & 679 & 673 & 681 & 574 & 769 & 568 \\
\hline & Total & 10,301 & 13,668 & 7062 & 4613 & 12,386 & 11,071 & 9793 \\
\hline \multirow{4}{*}{ Agriculture } & Forest & 4800 & 9465 & 1171 & 1442 & 2494 & 900 & 1913 \\
\hline & Grassland/Shubland & 1831 & 1871 & 1395 & 1086 & 500 & 1199 & 904 \\
\hline & Wetlands & 641 & 826 & 308 & 324 & 618 & 200 & 255 \\
\hline & Total & 7272 & 12,162 & 2874 & 2852 & 3612 & 2299 & 3072 \\
\hline $\begin{array}{c}\text { Developed and } \\
\text { Agriculture }\end{array}$ & Total & 17,573 & 25,830 & 9936 & 7465 & 15,998 & 13,370 & 12,865 \\
\hline
\end{tabular}

Demand for development in A2 drove widespread losses of existing agriculture, yet losses were more than offset by $>12,000 \mathrm{~km}^{2}$ of new agriculture, the most of any scenario. The Trends $86-92$ scenario followed with high total development conversion values, also at the expense of forests, but with more lands converting from agriculture to development than A2. Interestingly, development increases were even higher in the Trends $92-00$ scenario than the "business as usual" A1B scenario, suggesting an A1B world with lower rates of development than those documented in the late 20th century. The lowest conversion of land to development occurred in the regional/environmental focused B2 scenario. On average $8911 \mathrm{~km}^{2}$ of land was converted to development across SRES scenarios, only 9\% lower than the Trends Random result $\left(9793 \mathrm{~km}^{2}\right)$. The A2 scenario had the greatest gain in agricultural land with nearly double the increase of any scenario. The highest conversions were from forests, 
grassland/shrubland, and wetlands, which were highest for any scenario. The Trends $92-00$ had the smallest gain in agriculture. The environment-oriented B1 and B2 scenarios also had small relative gains in agriculture lands over the modeled period (Table 3). Conversions from agriculture into developed land are considered permanent transitions and represent a loss in potential reclamation or mitigation strategy.

\subsection{Forest Harvest}

Forest harvest intensity values of 1 represent all pixels harvested at least one time or the overall footprint of forest harvest. Forest harvest intensity values $>1$ equal areas harvested multiple times. The footprint of projected forest harvest ranged from $>54,000 \mathrm{~km}^{2}(17.1 \%)$ in the Trends $92-00$ scenario, to $>70,000 \mathrm{~km}^{2}(22.1 \%)$ in the A2 scenario (Table 4). While harvest intensity was not highest in A2, forest harvest footprint was greatest $\left(70,573 \mathrm{~km}^{2}\right)$. The A1B scenario had the highest harvest intensity (i.e., single pixels harvested multiple times), projecting the most area harvested two and three times over the modeled period. The B2 scenario had the second highest rate of overall forest harvest, given scenario assumptions of alternative energy use for forest harvest for cellulosic biofuels. Lowest overall forest harvest was projected in the Trends $92-00$.

Table 4. Area $\left(\mathrm{km}^{2}\right.$ and \%) of forest harvest in the Pacific Northwest for each modeled scenario. Harvest intensity values represent the periodicity of forest harvest, where values $>1$ equal area harvested multiple times.

\begin{tabular}{ccccccccc}
\hline \multirow{2}{*}{ LULC Scenarios } & \multicolumn{7}{c}{ Forest Harvest Intensity } \\
\cline { 2 - 9 } & \multicolumn{2}{c}{$\mathbf{1}$} & \multicolumn{2}{c}{$\mathbf{2}$} & \multicolumn{3}{c}{$\mathbf{3}$} & \multicolumn{2}{c}{ Total } \\
\hline A1B & 66,972 & $21.0 \%$ & 57,931 & $18.1 \%$ & 2162 & $0.7 \%$ & 127,065 & $39.8 \%$ \\
A2 & 70,573 & $22.1 \%$ & 36,845 & $11.5 \%$ & 574 & $0.2 \%$ & 107,992 & $33.8 \%$ \\
B1 & 66,705 & $20.9 \%$ & 25,730 & $8.1 \%$ & 216 & $0.1 \%$ & 92,651 & $29.0 \%$ \\
B2 & 69,412 & $21.7 \%$ & 46,750 & $14.6 \%$ & 1304 & $0.4 \%$ & 117,466 & $36.8 \%$ \\
Trends 86-92 & 60,064 & $18.8 \%$ & 48,033 & $15.0 \%$ & 1714 & $0.5 \%$ & 109,811 & $34.4 \%$ \\
Trends 92-00 & 54,534 & $17.1 \%$ & 21,316 & $6.7 \%$ & 317 & $0.1 \%$ & 76,167 & $23.8 \%$ \\
Trends Random & 61,287 & $19.2 \%$ & 21,833 & $6.8 \%$ & 124 & $0.0 \%$ & 83,244 & $26.0 \%$ \\
\hline
\end{tabular}

Potential forest harvest intensity combines both scenario agreement and harvest intensity (Figure 5). The mostly privately-held forests [19] of the Coast Range had the highest potential harvest intensity with $>27 \%$ of the ecoregion with projected values $>10$ (i.e., a minimum of 4 scenarios agree a pixel will be harvested 3 times or $\geq 5$ scenarios project 2 to 3 harvests). The Puget Lowlands had more than $20 \%$ of its land with values $>10$ as well, followed by $\sim 16 \%$ in the Willamette Valley and $<13 \%$ in the Cascades. Potential forest harvest intensity was lowest in the Sierra Nevada $(0.2 \%)$. Overall, $10.7 \%$ of the landscape in the Pacific Northwest had values $>10$. 
Figure 5. Potential forest harvest intensity in the Pacific Northwest from 2000 to 2100. Values from 1 to 18 represent the cumulative number of times a forested pixel was projected to be harvested across all seven scenarios. Ecoregion boundaries are shown and protected areas are indicated in black.

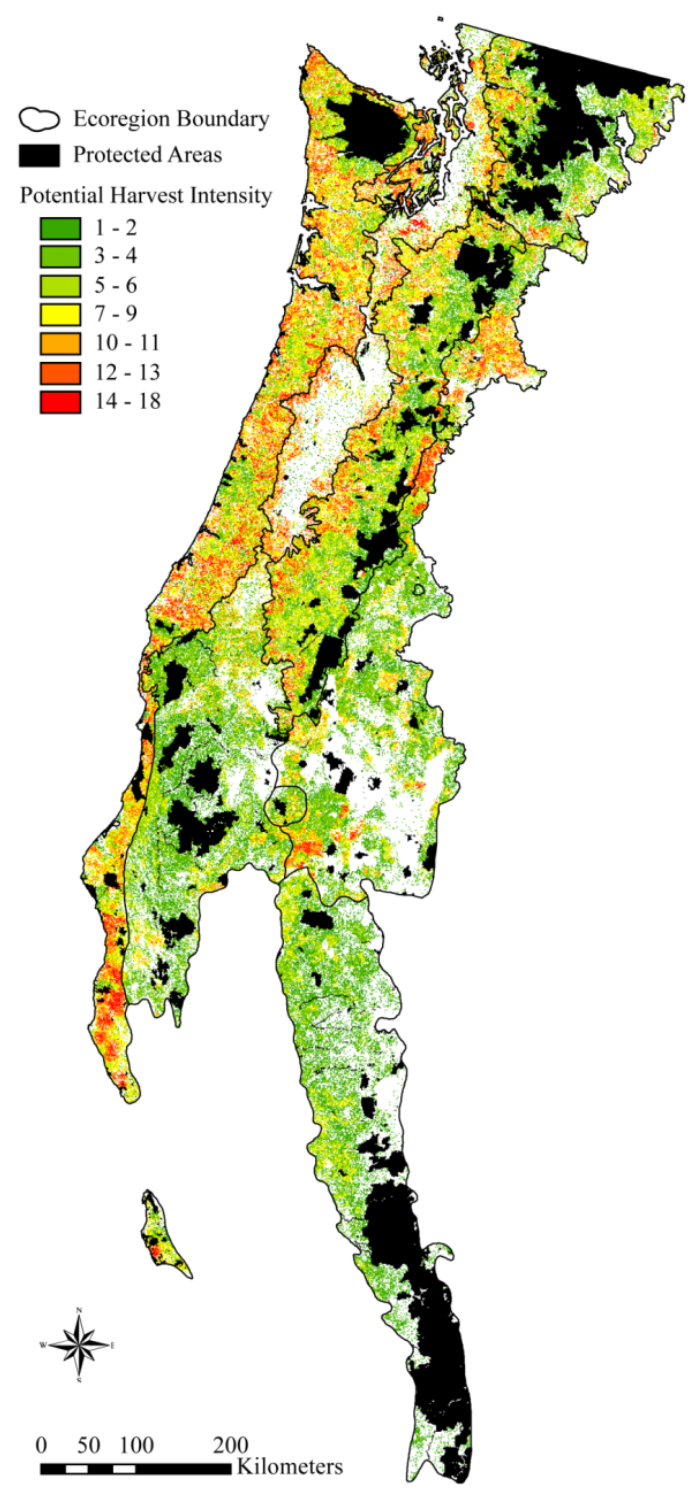

\subsection{Conversion Potential}

Conversion potential (CP) for all projected land-use transitions (i.e., development, agriculture, forest harvest) in the Pacific Northwest is expectedly high, given relatively high historic land-use change rates (Figure 6, Table 5). Approximately $11.4 \%\left(36,395 \mathrm{~km}^{2}\right)$ of the entire Pacific Northwest landscape had a CP of 7, where a land-use conversion was projected across all scenarios (i.e., highest possible value). More than half of the scenarios projected an estimated $33.6 \%\left(107,381 \mathrm{~km}^{2}\right)$ of the region experiencing land-use change $(\mathrm{CP} \geq 4)$ by 2100 (Table 5). By percent land area, the Coast Range had the greatest amount of land with highest CP values $\left(\sim 32 \%\right.$ of the ecoregion; $\left.17,132 \mathrm{~km}^{2}\right)$ followed by the smaller Puget Lowland ecoregion with over $20 \%\left(3298 \mathrm{~km}^{2}\right)$. The Sierra Nevada had the lowest $\mathrm{CP}$, both in terms of land area and percent total ecoregion. 
Figure 6. Conversion potential into developed, agriculture and forest harvest lands in the Pacific Northwest from 2000 to 2100 . Values 1-7 represent the number of scenarios projecting land-use conversion over the modeled period. Ecoregion boundaries are shown and protected areas are indicated in black.

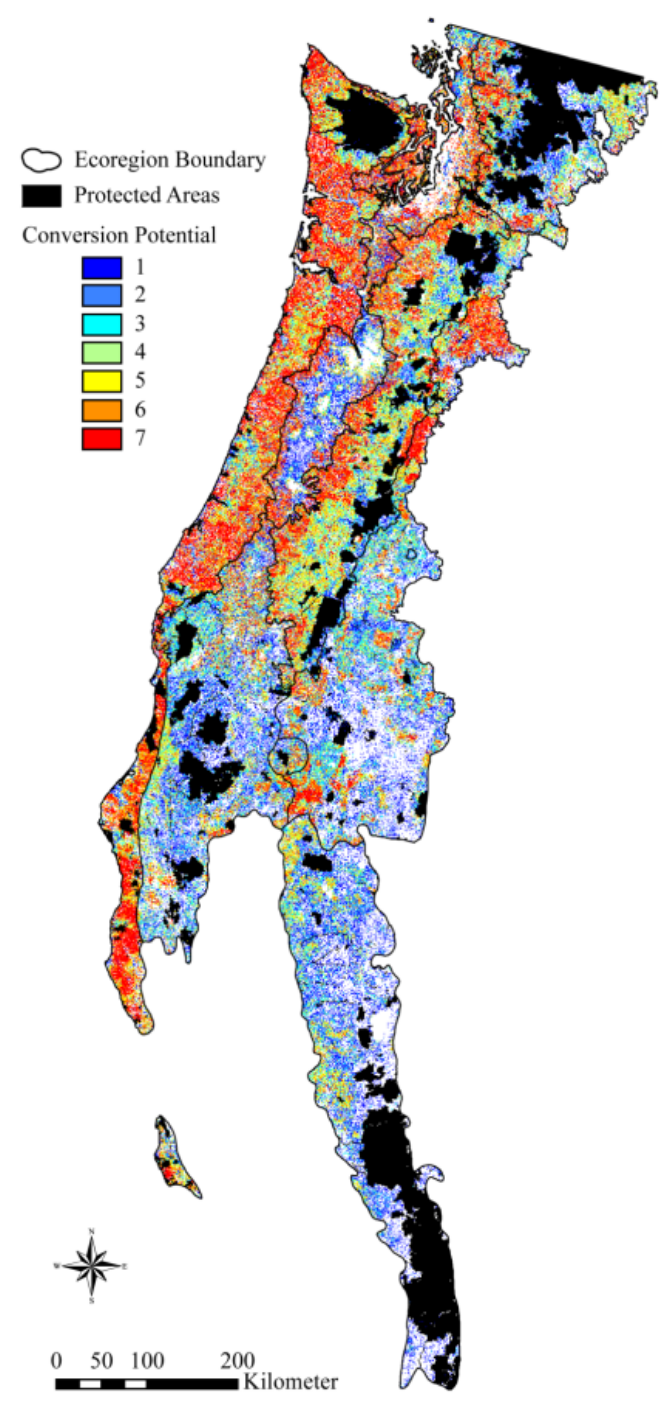

Table 5. Conversion potential by ecoregion area $\left(\mathrm{km}^{2}\right)$ in the Pacific Northwest by 2100 . Values 1-7 represent the number of scenarios projecting land-use conversion over the modeled period.

\begin{tabular}{ccccccccc}
\hline \multirow{2}{*}{ Ecoregion } & $\mathbf{8}$ Conversion Potential & \multirow{2}{*}{ \% Area in 7 } \\
\cline { 2 - 8 } & $\mathbf{1}$ & $\mathbf{2}$ & $\mathbf{3}$ & $\mathbf{4}$ & $\mathbf{5}$ & $\mathbf{6}$ & $\mathbf{7}$ & \\
\hline Coast Range & 2417 & 1390 & 2041 & 3342 & 5104 & 8386 & 17,132 & $31.7 \%$ \\
Puget Lowland & 1664 & 1110 & 656 & 599 & 1263 & 2729 & 3298 & $20.0 \%$ \\
Willamette Valley & 2875 & 1440 & 687 & 598 & 865 & 1292 & 1836 & $12.3 \%$ \\
Cascades & 2613 & 2722 & 3918 & 5082 & 5462 & 5873 & 5951 & $12.8 \%$ \\
Sierra Nevada & 6966 & 4083 & 2705 & 2083 & 1794 & 978 & 231 & $0.4 \%$ \\
East Cascades & 7244 & 4956 & 4765 & 4097 & 3413 & 3899 & 4699 & $8.4 \%$ \\
North Cascades & 2072 & 1787 & 1775 & 1927 & 1671 & 1367 & 1620 & $5.3 \%$ \\
Klamath Mountains & 6805 & 5375 & 4508 & 3594 & 3061 & 2507 & 1628 & $3.4 \%$ \\
\hline TOTAL & 32,656 & 22,863 & 21,055 & 21,322 & 22,633 & 27,031 & 36,395 & $11.4 \%$ \\
\hline
\end{tabular}




\subsection{Protected Areas}

The North Cascades had the largest percentage of protected area, while the Sierra Nevada had the largest areal extent of protected area (Table 6). The Willamette Valley and Puget Lowlands have the least amount of protected area by both percent area and total area. Overall $>54,000 \mathrm{~km}^{2}$ or nearly $17 \%$ of land in the Pacific Northwest is protected.

Table 6. Protected areas $\left(\mathrm{km}^{2}\right)$ of the Pacific Northwest by ecoregion.

\begin{tabular}{cccccc}
\hline Ecoregion & $\begin{array}{c}\text { Area } \\
\left(\mathbf{k m}^{\mathbf{2}}\right)\end{array}$ & $\begin{array}{c}\text { GAP 1 } \\
\mathbf{( k m}^{\mathbf{2}}\end{array}$ & $\begin{array}{c}\text { GAP 2 } \\
\mathbf{( k m}^{\mathbf{2}}\end{array}$ & $\begin{array}{c}\text { Total Protected } \\
\mathbf{( k m}^{\mathbf{2}}\end{array}$ & $\begin{array}{c}\text { Total Protected } \\
\mathbf{( \% )}\end{array}$ \\
\hline Coast Range & 53,979 & 2799 & 2238 & 5037 & $9.3 \%$ \\
Puget Lowland & 16,456 & 29 & 301 & 330 & $2.0 \%$ \\
Willamette Valley & 14,874 & 0 & 186 & 186 & $1.2 \%$ \\
Cascades & 46,437 & 2196 & 7119 & 9315 & $20.1 \%$ \\
Sierra Nevada & 52,866 & 12,775 & 3179 & 15,954 & $30.2 \%$ \\
East Cascades & 56,115 & 283 & 2598 & 2881 & $5.1 \%$ \\
North Cascades & 30,312 & 3536 & 9618 & 13,154 & $43.4 \%$ \\
Klamath Mountains & 48,544 & 5127 & 2149 & 7276 & $15.0 \%$ \\
\hline Total & 319,583 & 26,745 & 27,388 & 54,133 & $16.9 \%$ \\
\hline
\end{tabular}

\subsection{Conversion Threat Index}

CTI values of high and very high represent $\geq 5$ scenarios in agreement that a pixel will convert within $\geq 20 \mathrm{~km}$ of a protected area boundary over the modeled period (Table 7). Our results for the Pacific Northwest indicate $>27,081 \mathrm{~km}^{2}$ of land with very high projected CTI values (Figure 7, Table 7). Approximately $17 \%$ of the landscape in the Pacific Northwest fall within the high to very high CTI classes. Lands categorized with medium CTI values comprise $\sim 15 \%$ of the total land area in the region. $\left(47,985 \mathrm{~km}^{2}\right)$. While medium CTI land area may not be in closest proximity to protected areas, these land-use conversions do reflect increasing regional land-use pressure over the coming decades which may impact the integrity of existing protected areas. At the ecoregion-scale, nearly $22 \%$ of the total land area in the Coast Range and over $16 \%$ of the Puget Lowland had very high CTI values (Table 7). Cumulatively, lands categorized with high to very high CTI values comprise nearly $40 \%$ $\left(20,992 \mathrm{~km}^{2}\right)$ of the Coast Range, $30 \%\left(4943 \mathrm{~km}^{2}\right)$ of the Puget Lowland, and $24 \%\left(11,141 \mathrm{~km}^{2}\right)$ of the Cascades.

Table 7. Conversion Threat Index from 2000 to 2100 for ecoregions in the Pacific Northwest.

\begin{tabular}{ccccccccc}
\hline & \multicolumn{1}{c}{ CTI Value } \\
\cline { 2 - 9 } Low & \multicolumn{2}{c}{ Medium } & \multicolumn{2}{c}{ High } & \multicolumn{2}{c}{ Very High } \\
\hline Coast Range & 5230 & $9.7 \%$ & 10,385 & $19.2 \%$ & 9264 & $17.2 \%$ & 11,728 & $21.7 \%$ \\
Puget Lowland & 1697 & $10.3 \%$ & 2605 & $15.8 \%$ & 2267 & $13.8 \%$ & 2676 & $16.3 \%$ \\
Willamette Valley & 1743 & $11.7 \%$ & 1918 & $12.9 \%$ & 1273 & $8.6 \%$ & 888 & $6.0 \%$ \\
Cascades & 5963 & $12.8 \%$ & 11,118 & $23.9 \%$ & 6058 & $13.0 \%$ & 5083 & $10.9 \%$ \\
Sierra Nevada & 5893 & $11.1 \%$ & 3529 & $6.7 \%$ & 674 & $1.3 \%$ & 302 & $0.6 \%$ \\
East Cascades & 8380 & $14.9 \%$ & 7609 & $13.6 \%$ & 3731 & $6.6 \%$ & 2787 & $5.0 \%$ \\
\hline
\end{tabular}


Table 7. Cont.

\begin{tabular}{cccccccccc}
\hline & \multicolumn{1}{c}{ CTI Value } \\
\cline { 2 - 10 } & \multicolumn{2}{c}{ Low } & \multicolumn{2}{c}{ Medium } & \multicolumn{2}{c}{ High } & \multicolumn{2}{c}{ Very High } \\
\hline North Cascades & 2784 & $9.2 \%$ & 3542 & $11.7 \%$ & 1604 & $5.3 \%$ & 1966 & $6.5 \%$ \\
Klamath Mountains & 7785 & $16.0 \%$ & 7279 & $15.0 \%$ & 2330 & $4.8 \%$ & 1651 & $3.4 \%$ \\
\hline Total & $\mathbf{3 9 , 4 7 5}$ & $\mathbf{1 2 . 4 \%}$ & $\mathbf{4 7 , 9 8 5}$ & $\mathbf{1 5 . 0 \%}$ & $\mathbf{2 7 , 2 0 1}$ & $\mathbf{8 . 5 \%}$ & $\mathbf{2 7 , 0 8 1}$ & $\mathbf{8 . 5 \%}$ \\
\hline
\end{tabular}

Figure 7. Conversion threat index (CTI) in the Pacific Northwest from 2000 to 2100.

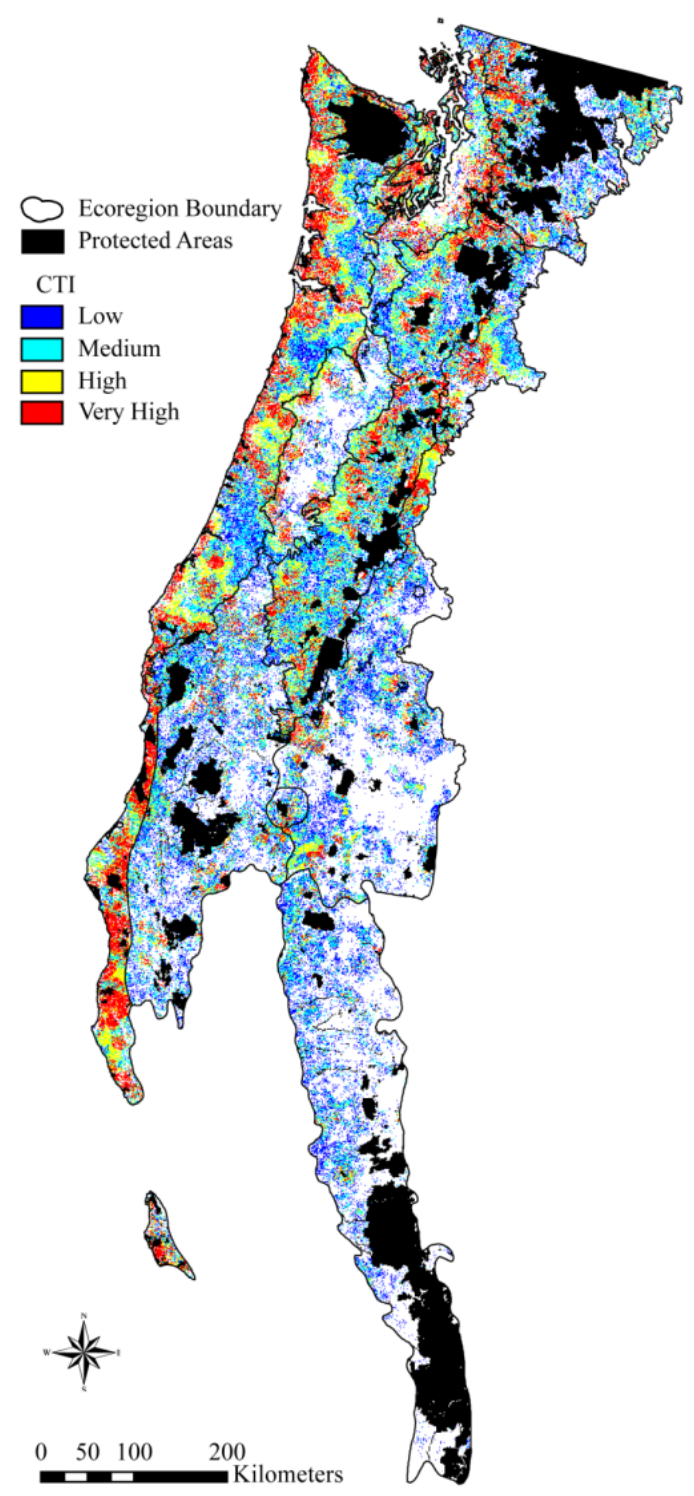

\section{Discussion}

Land use in areas adjacent to and at varying proximity from protected areas can influence the integrity of protected areas as a conservation tool $[22,23,25,26]$. Local land use can have direct impacts on biodiversity via habitat loss, increased fragmentation and isolation, reduced dispersal capability, and non-native invasions. Non-local land uses can have broad reaching indirect impacts as well, impacting habitat corridors, increasing invasives, and further isolating existing protected areas [30]. Assessing the threat of local and non-local landscape level land use is essential for rapidly identifying 
regions at greater risk of future land-use conversion and protected areas at greater risk of adjacent land use. Our scenario land-use projections were divergent, exemplifying inherent variation across scenario assumptions and trajectories. Divergence in land-use projections was expected to lower potential scenario agreement and thus conversion potential. Lower conversion potential would naturally lead to underestimation of conversion threat index (CTI) values, a preferred outcome to overestimation. As expected, the A2 emission scenario with rapid population growth, low economic growth, fossil fuel dependence, and minimal resource protection had the highest projected changes in non-harvest related land use (i.e., conversions to developed and agriculture only) in the Pacific Northwest. In contrast, the B2 scenario had the lowest projected changes in non-harvest related land use, due to scenario assumptions of resource protection, low population growth, and innovative use of technology. All three Trends scenarios (i.e., 86-92, 92-00, and random) had similar projected outcomes for non-forest related land use, with the Trends $86-92$ having the highest amount of change $\left(15,998 \mathrm{~km}^{2}\right)$ and the Trends Random the lowest $\left(12,865 \mathrm{~km}^{2}\right.$, Table 3).

When forest harvest was included in overall land-use change projections, the A1B scenario projected $144,638 \mathrm{~km}^{2}$ (45.2\% of $319,583 \mathrm{~km}^{2}$ of land in the Pacific Northwest) would be impacted by human land use (i.e., developed, agriculture, and forest harvest) by 2100 . The A1B had the highest forest harvest impact of any scenario, given the global nature of the scenario and balanced energy sector, including tree planting and harvest for cellulosic biofuels [43]. The A2 scenario projected 133,822 $\mathrm{km}^{2}$ (41.9\%) of available land experiencing human land use by 2100. The A2 scenario is one of the high but not highest emission scenarios [43]. The Trends 86-92 scenario had the highest projected amount of forest harvest this century (34\%) and the Trends 92-00 had the lowest. These low rates were a continuation of the historic low rates of forest harvest which occurred in the 1990's due to the virtual halting of all forest harvest on federally managed lands in 1991, following protection of the Northern spotted owl (Strix occidentalis caurina). The issue was not resolved until 1993 when the Northwest Forest Plan was adopted [91]. As a result, between 1965 and 1988, timber sold from Pacific Northwest national forests fluctuated annually between 3 and 4 billion board feet [91]. However, in 1991 sales dropped to less than 1 billion board feet, a level maintained throughout the 1990s [91]. Based on the future SRES scenarios developed by Sleeter et al. [60], future harvest rates on public lands will not increase to pre-protection 1986-1992 levels. However, forest harvest on private lands will intensify given increased global demand for wood products and to offset reduced allowable harvest on public lands this century [60].

The Coast Range had the highest CP by 2100 of any ecoregion in the Pacific Northwest, is the 2nd largest ecoregion by land area, and only $9.3 \%$ of its highly productive forests are protected. The remaining land is privately-owned and has had historically very high rates of forest harvest compared to federally managed land [63]. An estimated $21.7 \%$ of land area in the Coast Range had very high CTI values (Table 7). Additional protected lands or corridors would likely increase connectivity of protected areas in the Coast Range. The comparatively small Puget Lowlands, with only $2.0 \%$ of its lands protected, had an estimated $16.3 \%$ of its land area with very high CTI values (Table 7). Despite minimal protected area, lands already designated will likely be challenged by proximal land use this century. This is not surprising given the region's complex land-use mosaic and highest rates of historic land-use change documented in the western United States [19]. The Cascades also had high CP values and nearly $11 \%$ of its land with very high CTI values, due to over $20 \%$ of its land protected and high 
rates of forest harvest. The Willamette Valley is the least protected ecoregion (1.2\%) resulting in relatively low CTI values, despite relatively high CP values $(12.3 \%$ of ecoregion with $\mathrm{CP}=7)$ (Table 5$)$. The Sierra Nevada was the least threatened ecoregion, according to our CTI results, followed by the Klamath Mountains and the East Cascades. An estimated 30.2\% of land in the Sierra Nevada is protected, second only to the $43.4 \%$ of land in the North Cascades. Overall, $11.4 \%$ (Table 5) of the Pacific Northwest was projected by all scenarios to undergo land-use conversion and $8.5 \%$ of these projected conversions will occur within close proximity to protected areas (i.e., very high CTI values).

Our conversion potential results were similar to those resulting from economic-based projections of future land use in the U.S. under four different policy scenarios [25]. This work highlighted the Coast Range (11\%-15\%), Puget Lowlands (31\%-40\%), and Willamette Valley (51\%-81\%) with high rates of change [25]. However, this study did not consider forest harvest as a land-use change, thus lowering projections for the Coast Range and all forested ecoregions in the Pacific Northwest compared to our results. Under all four scenarios examined, urban (i.e., developed) land use increased $50 \%-100 \%$ in heavily populated ecoregions in the Pacific Northwest and forest declines were projected for the Coast Range [25]. Our values were lower overall, but the change trajectories were the same. Although, differences in classification and modeling approaches make direct comparisons challenging, our CTI results were in alignment with global scale projections of land-use conversions by 2100 occurring within $50 \mathrm{~km}$ buffers surrounding protected areas for both secondary lands (i.e., those recovering from disturbance such as forest harvest) and cropland and pasture (our combined agriculture class) [90]. Again, classification and scale issues make direct comparison of results minimally effective. Research examining national historic housing growth rates near protected areas highlighted the Pacific Northwest with 200\%-400\% housing growth rates between 1940 and 2000 [30].

We recognize not all land uses have adverse impacts on local species or habitat and that species and communities have varying response capabilities given the land-use type and intensity. However, it was not our intent to disentangle the various land-use types or most common conversions in either the CP or CTI metrics. The single Monte Carlo iteration has limited interpretive capacity since model uncertainty is not quantified. We are currently looking at methods to best incorporate multiple Monte Carlo spatial simulations into a single map output representing model uncertainty. This requires automated post-processing methods still under development and advanced computing capacity. Overall, spatially-explicit LULC scenario data for the United States are sparse and our goal was to fill this information gap. While scenarios were not absolute in terms of predictive outcome, they represent plausible future conditions, based on historic rates of land-use change, and offer managers and planners a view of alternative future landscape conditions. The utility of LULC scenarios goes beyond the conservation application described herein and can be applied to any landscape or land-use question. State classes can be attributed with any existing spatial data.

Land use intensification on unprotected lands will increasingly challenge the integrity of existing protected areas in coming decades. Rapid LULC assessments will be important, especially in data poor environments with high biodiversity. These regions often lack resources to conduct regional biodiversity assessments. Using a STSM, LULC scenarios can be generated from a broad range of freely available global datasets and analyzed. This method can accompany more traditional species or community level data collection techniques where possible, given limited availability of both time and resources. STSM of LULC scenarios is an effective method of rapid, landscape level analysis of LULC pressures and 
can also be used to visualize land-use mitigation strategies. The modeling approach can be incorporated into assessments of LULC change threats at a variety of spatial scales. Landscape level, scenario-based approaches such as these may prove vital in identifying existing protected areas at greater risk from regional land-use threats.

\section{Conclusions}

State-and-transition simulation models are well suited for modeling future LULC change scenarios. The simplicity of the ST-Sim model design and raster simulator makes it a useful tool in examining alternative scenario futures for a given landscape. Overlays of spatially explicit output from multiple scenarios highlight areas with higher probability of future LULC conversion. When areas with highest conversion potential are combined with proximity to protected area measurements, ecoregions with protected areas most threatened by potential future land conversion can be identified. Our CTI metric indicated the North Cascades and Sierra Nevada have the greatest relative amount (by total ecoregion area) of protected areas with the lowest threat of proximal land use. In contrast, protected areas in the Coast Range, Puget Lowland, and Cascades would likely be most threatened by regional land-use within close proximity to protected areas. Our results indicated the Puget Lowland is most vulnerable to future land-use conversion, based on very high CTI values and very low amount of protected land (2.01\%). Such information can assist land managers in developing landscape level approaches to conservation planning and management. Our CTI can also be used in additional spatial analysis where spatial data are available, such as species richness, climatic tolerance, habitat range modeling, migration corridor, and planning zone data. While scenarios have obvious limitations and do not represent absolute future outcomes, they do allow a previously unavailable perspective into plausible LULC futures based on empirical historic data. Analysis of land-use conversion potential, driven by historical change rates is an effective strategy for rapid assessment of lands most likely to undergo land-use conversion this century.

Human land-use demand in the Pacific Northwest will only continue to grow in coming decades $[25,27,55,60]$. Methods to help identify potential habitat at greatest risk of conversion will be essential, if effective management strategies are to succeed. Habitat availability will likely be the most critical determinant of species success [4-6]. When the factors of human land use are combined with projected changes in climate and potential species range shifts, the challenges to biodiversity are only magnified [92,93]. Drought conditions in the Pacific Northwest are projected to intensify in coming decades [94] which will likely add to the problem. Given projected increases in land use and projected changes in climate, species and communities will likely face increasingly difficult adaptive capacity challenges [95]. Management and conservation planning strategies incorporating landscape level land-use threats into their decision-making processes will be better situated to respond to these challenges. Our CTI index map lends itself to a wide range of additional species, community, and ecosystem level analyses (e.g., overlay with existing corridor analysis, climatic envelop data, etc.). Incorporation of CTI results with landscape-scale indicators of biodiversity vulnerability to climate change [92] would greatly improve our ability to target regions at greatest risk from both land use and climate change. 


\section{Acknowledgments}

This work was funded by the U.S. Geological Survey's Climate and Land Use Change Research and Development Program. We would like to thank Colin Daniel and Leonardo Frid at Apex RMS who developed the ST-Sim model and provided excellent training and continuous user support.

\section{Authors Contributions}

Tamara S. Wilson is the principal author of the manuscript, conducted the majority of the literature review, and developed the concept of using distance to protected areas as a metric for assessing land-use conversion threats. She authored the majority of the manuscript utilizing various input and editing suggestions from co-authors (described below). Wilson handled the ST-Sim model runs, data output, data processing and analysis, and graphics/table creation, the bulk of the writing, the and summary of findings.

Benjamin M. Sleeter was responsible for developing all the land use and land cover scenarios discussed in the paper and parameterizing land-use demand in ST-Sim. Sleeter developed the concept of utilizing a STSM platform to model changes in land use and was instrumental in identifying important components to be used in the spatial multipliers. He authored the section on scenario downscaling and use of the IPCC SRES scenarios. He also conducted a thorough review of the manuscript and provided background literature on scenarios.

Rachel R. Sleeter was primarily responsible for creating and managing all of the spatial multipliers utilized in the ST-Sim model runs. Rachel contributed to the section describing the spatial multipliers and also conducted a thorough review of the manuscript.

Christopher E. Soulard was instrumental in creating and incorporating the new, harmonized land use and land cover dataset as the initial condition state class for the ST-Sim model. He authored the section on the harmonized land cover and also reviewed the manuscript and offered useful insights as to its improvement.

\section{Conflicts of Interest}

The authors declare no conflict of interest.

\section{Disclaimer}

Any use of trade, firm, or product names is for descriptive purposes only and does not imply endorsement by the U.S. Government.

\section{References}

1. Dale, V.H. The relationship between land-use change and climate change. Ecol. Appl. 1997, 7, 753-769.

2. Turner, B.L., II, Clark, W.C., Kates, R.M., Richards, J.F., Mathews, J.T., Meyer, M.B., Eds. The Earth as Transformed by Human Action: Global and Regional Changes in the Biosphere over the Past 300 Years; Cambridge University Press: Cambridge, UK, 1990; p. 713. 
3. Vitousek, P.M.; Mooney, H.A.; Lubchenco, J.; Melillo, J.M. Human domination of earth's ecosystems. Science 1997, 277, 494-499.

4. Sala, O.E.; Chapin, F.S.; Armesto, J.J.; Berlow, E.; Bloomfield, J.; Dirzo, R.; Huber-Sanwald, E.; Huenneke, L.F.; Jackson, R.B.; Kinzig, A.; et al. Global biodiversity scenarios for the year 2100. Science 2000, 287, 1770-1774.

5. Soule, M.E. Conservation: Tactics for a constant crisis. Science 2001, 253, 744-750.

6. Seabloom, E.W.; Dobson, A.P.; Stoms, D.M. Extinction rates under nonrandom patterns of habitat loss. Proc. Natl. Acade. Sci. USA 2002, 99, 11229-11234.

7. Swaty, R.; Blankenship, K.; Hagen, S.; Fargione, J.; Smith, J.; Patton, J. Accounting for ecosystem alteration doubles estimates of conservation risk in the conterminous United States. PLoS One 2011, 6, e23002.

8. Davies, R.G.; Orme, D.L.; Olson, V.; Thomas, G.H.; Ross, S.G.; Ding, T.-S.; Rasmussen, P.C.; Stattersfield, A.J.; Bennett, P.M.; Blackburn, T.M.; et al. Human impacts and the global distribution of extinction risk. Proc. R. Soc. Biol. Sci. 2006, 273, 2127-2133.

9. Rittenhouse, C.D.; Pidgeon, A.M.; Albright, T.P.; Culbert, P.D.; Clayton, M.K.; Flather, C.H.; Masek, J.G.; Radeloff, V.C. Land-cover change and avian diversity in the conterminous United States. Conserv. Biol. 2012, 26, 821-829.

10. Foley, J.A.; DeFries, R.; Asner, G.P.; Barford, C.; Bonan, G.; Carpenter, S.R.; Chapin, F.S.; Coe, M.T.; Daily, G.C.; Gibbs, H.K.; et al. Global consequences of land use. Science 2005, $309,570-574$.

11. Romero, H.; Ihl, M.; Rivera, A.; Zalazar, P.; Azocar, P. Rapid urban growth, land-use changes and air pollution in Santiago, Chile. Atmos. Environ. 1999, 33, 4039-4047.

12. Ross, Z.; English, P.B.; Scalf, R.; Gunier, R.; Smorodinsky, S.; Wall, S.; Jerrett, M. Nitrogen dioxide prediction in southern California use land use regression modeling: Potential for environmental health analyses. J. Expos. Sci. Environ. Epidemiol. 2006, 16, 106-114.

13. Houghton, R.A.; Hackler, J.L. Carbon Flux to the Atmosphere from Land-Use Changes: 1850 to 1990; ORNL/CDIAC-131, NDP-050/R1; Carbon Dioxide Information Analysis Center, U.S. Department of Energy, Oak Ridge National Laboratory: Oak Ridge, TN, USA, 2001; p. 18.

14. Bonan, G.B. Effects of land use on the climate of the United States. Clim. Chang. 1997, 37, 449-486.

15. Pielke, R.A.; Marland, G.; Betts, R.A.; Chase, T.N.; Eastman, J.L.; Niles, J.O.; Niyogi, D.D.S.; Running, S.W. The influence of land-use change and landscape dynamics on the climate system: Relevance to climate-change policy beyond the radiative effect of greenhouse gases. Philos. Trans. R. Soc. Lond. 2002, 360, 1705-1719.

16. Lawrence, P.L.; Chase, T.N. Investigating the climate impacts of global land cover change in the community climate system model. Int. J. Clim. 2010, 30, 2066-2087.

17. Pitman, A.J.; Avila, F.B.; Abramowitz, G.; Wang, Y.P.; Phipps, S.J.; de Noblet-Ducoudre, N. Importance of background climate in determining the impact of land-cover change on regional climate. Nat. Clim. Chang. 2011, 1, 472-475.

18. Fischer, J.; Lindenmayer, D.B. Landscape modification and habitat fragmentation: A synthesis. Glob. Ecol. Biogeogr. 2007, 16, 265-280. 
19. Sleeter, B.M., Wilson, T.S., Acevedo, W., Eds. Status and Trends of Land Change in the Western United States-1973 to 2000; U.S. Geological Survey Professional Paper 1794-A; U.S. Geological Survey: Reston, VA, USA, 2012; p. 324.

20. Primack, R.B. Essentials of Conservation Biology, 5th ed.; Sinauer Associates, Inc.: Sunderland, MA, USA, 2010; p. 601.

21. Cole, D.N.; Landres, P.B. Threats to wilderness ecosystems: Impacts and research needs. Ecol. Appl. 1996, 6, 168-184.

22. Hansen, A.J.; DeFries, R. Ecological mechanisms linking protected areas to surrounding lands. Ecol. Appl. 2007, 17, 974-988.

23. Hansen, A.J.; Rasker, R.; Maxwell, B.; Rotella, J.J.; Johnson, J.D.; Parmenter, A.W.; Langner, U.; Cohen, W.B.; Lawrence, R.L.; Kraska, M.P.V. Ecological causes and consequences of demographic change in the New West. BioScience 2002, 52, 151-162.

24. Joppa, L.N.; Loarie, S.R.; Pimm, S.L. On the protection of "protected areas." Proc. Natl. Acad. Sci. USA 2008, 105, 6673-6678.

25. Radeloff, V.C.; Nelson, E.; Plantinga, A.J.; Lewis, D.J.; Helmers, D.; Lawler, J.J.; Withey, J.C.; Beaudry, F.; Martinuzzi, S.; Butsic, V.; et al. Economic-based projections of future land use in the conterminous United States under alternative policy scenarios. Ecol. Appl. 2012, 22, 1036-1049.

26. Hamilton, C.M.; Martinuzzi, S.; Plantinga, A.J.; Radeloff, V.C.; Lewis, D.J.; Thogmartin, W.E.; Heglund, P.J.; Pidgeon, A.M. Current and future land use around a nationwide protected area network. PLoS One 2013, 8, e55737.

27. Wade, A.A.; Theobald, D.M. Residential development encroachment on U.S. protected areas. Conserv. Biol. 2010, 24, 151-161.

28. Pitelka, L.F. Plant migration and climate change: A more realistic portrait of plant migration is essential to predicting biological responses to global warming in a world drastically altered by human activity. Am. Sci. 1997, 85, 464-473.

29. Ritters, K.H.; Wickham, J.D. How far to the nearest road? Front. Ecol. Environ. 2003, 1, 125-129.

30. Radeloff, V.C.; Stewart, S.I.; Hawbaker, T.J.; Gimmi, U.; Pidgeon, A.M.; Flather, C.H.; Hammer, R.B.; Helmers, D.P. Housing growth in and near United States protected areas limits their conservation value. Proc. Natl. Acad. Sci. USA 2010, 107, 940-945.

31. Nagenda, H. Do parks work? Impact of protected areas on land cover clearing. AMBIO 2008, 37, 330-337.

32. McLaughlin, A.; Mineau, P. The impact of agricultural practices on biodiversity. Agric. Ecosyst. Environ. 1995 55, 201-212.

33. Neary, D.G.; Hornbeck, J.W. Impacts of harvesting and associated practices on off-site environmental quality. In Impacts of Forest Harvesting on Long-Term Site Productivity, 1st ed.; Dyck, W.J., Cole, D.W., Comerford, N.B., Eds.; Chapman and Hall: Suffolk, VA, USA, 1994; pp. 81-118.

34. Nave, L.E.; Vance, E.D.; Swanston, C.W.; Curtis, P.S. Harvest impacts on soil carbon storage in temperate forests. For. Ecol. Manag. 2010, 259, 857-866.

35. Ricketts, T.; Imhoff, M. Biodiversity, urban areas, and agriculture: Locating priority ecoregions for conservation. Conserv. Biol. 2003, $8,1$. 
36. Wilson, K.; Pressey, R.L.; Newton, A.; Burgman, M.; Possingham, H.; Weston, C. Measuring and incorporating vulnerability into conservation planning. Environ. Manag. 2005, 35, 527-543.

37. McDonald, R.I.; Yuan-Farrell, C.; Fievet, C.; Moeller, M.; Kareiva, P.; Foster, D.; Gragson, T.; Kinzig, A.; Kuby, L.; Redman, C. Estimating the effect of protected lands on the development and conservation of their surroundings. Conserv. Biol. 2007, 21, 1526-1536.

38. Wilson, T.S.; Sleeter, B.M.; Davis, A.W. Projected future land use threats to California's protected areas. Reg. Environ. Chang. 2014, under review.

39. Gude, P.H.; Hansen, A.J.; Jones, D.A. Biodiversity consequences of alternative future land use scenarios in greater Yellowstone. Ecol. Appl. 2007, 17, 1004-1018.

40. Margules, C.R.; Pressey, R.L. Systematic conservation planning. Nature 2000, 405, 243-253.

41. Defries, R.; Hansen, A.; Turner, B.L.; Reid, R.; Liu, J. Land use change around protected areas: Management to balance human needs and ecological function. Ecol. Appl. 2007, 17, 1031-1038.

42. Newburn, D.; Reed, S.; Berck, P.; Merenlender, A. Economics and land-use change in prioritizing private land conservation. Conserv. Biol. 2005, 19, 1411-1420.

43. Nakicenovic, N., Swart, R., Eds. IPCC Special Report on Emission Scenarios; Cambridge University Press; Cambridge, UK; p. 570.

44. Heistermann, M.; Müller, C.; Ronneberger, K. Land in sight? Achievements, deficits, and potentials of continental to global scale land-use modeling. Agric. Ecosyst. Environ. 2006, $114,141-158$.

45. Rounsevell, M.D.A.; Reginster, I.; Araújo, M.B.; Carter, T.R.; Dendoncker, N.; Ewert, F.; House, J.I.; Kankaanpää, S.; Leemans, R.; Metzger, M.J.; et al. A coherent set of future land use change scenarios for Europe. Agric. Ecosyst. Environ. 2006, 114, 57-68.

46. Alcamo, J.; Kok, K.; Busch, G.; Priess, J. Searching for the future of land: Scenarios from the local to global scale. In Environmental Futures: The Practice of Environmental Scenario Analysis; Alcamo, J., Ed.; Elsevier: Amsterdam, The Netherlands, 2008; pp. 67-103.

47. Luoto, M.; Virkkala, R.; Heikkinen, R.K. The role of land cover in bioclimatic models depends on spatial resolution. Glob. Ecol. Biogeogr. 2007, 16, 34-42.

48. Strayer, D.L.; Beighley, R.E.; Thompson, L.C.; Brooks, S.; Nilsson, C.; Pinay, G.; Naiman, R.J. Effects of land cover on stream ecosystems: Roles of empirical models and scaling issues. Ecosytems 2003, 6, 407-423.

49. Zhao, S.; Liu, S.; Sohl, T.; Young, C.; Werner, J. Land use and carbon dynamics in the southeastern United States from 1992 to 2050. Environ. Res. Lett. 2013, 8, 044022:9.

50. Sohl, T.L.; Sayler, K.L.; Bouchard, M.A.; Reker, R.R.; Friesz, A.M.; Bennett, S.L.; Sleeter, B.M.; Sleeter, R.R.; Wilson, T.S.; Knuppe, M.; et al. Spatially explicit modeling of 1992 to 2100 land cover and forest stand age for the conterminous United States. Ecol. Appl. 2013, doi: 10.1890/13-1245.1.

51. Wear, D.N. Forecasts of County-Level Land Uses Under Three Future Scenarios: A Technical Document Supporting the Forest Service 2010 RPA Assessment; Gen. Tech. Rep. SRS-141; U.S. Department of Agriculture Forest Service, Southern Research Station: Asheville, NC, USA, $2011 ;$ p. 41. 
52. Zhu, Z., Ed. Baseline and Projected Future Carbon Storage and Greenhouse-Gas Fluxes in the Great Plains Region of the United States; U.S. Geological Survey Professional Paper 1787; U.S. Geological Survey: Reston, VA, USA, 2011; p. 28.

53. Sleeter, B.M.; Sohl, T.L.; Wilson, T.S.; Sleeter, R.R.; Soulard, C.E.; Bouchard, M.A.; Sayler, K.L.; Reker, R.R.; Griffith, G.E. Projected land-use and land-cover change in the Western United States. In Baseline and Projected Future Carbon Storage and Greenhouse-Gas Fluxes in Ecosystems of the Western United States; U.S. Geological Survey Professional Paper 1797A; Zhu, Z., Reed, B.C., Eds.; U.S. Geological Survey: Reston, VA, USA, 2012; pp. 65-86.

54. Sohl, T.L.; Sleeter, B.M.; Sayler, K.L.; Bouchard, M.A.; Reker, R.R.; Bennett, S.L.; Sleeter, R.R.; Kanengieter, R.L.; Zhu, Z. Spatially explicit land-use and land-cover scenarios for the Great Plains of the United States. Agric. Ecosyst. Environ. 2012, 153, 1-15.

55. Wilson, T.S.; Sleeter, B.S.; Sohl, T.L.; Griffith, G.; Acevedo, W.; Bennett, S.; Bouchard, M.; Reker, R.; Ryan, C.; Sayler, K.L.; et al. Future Scenarios of Land-Use and Land-Cover Change in the United States: The Marine West Coast Forests Ecoregion; U.S. Geological Survey Open File Report 2012-1252; U.S. Geological Survey: Reston, VA, USA, 2012; p. 14.

56. Arnell, N.W.; Livermore, M.J.L.; Kovats, S.; Levy, P. Climate and socioeconomic scenarios for global-scale climate change impacts assessments: Characterizing the SRES storylines. Glob. Environ. Chang. 2004, 14, 3-20.

57. Gaffin, S.R.; Rosenzweig, C.; Xing, X.; Yetman, G. Downscaling and geo-spatial gridding of socio-economic projections from the IPCC Special Report on Emissions Scenarios (SRES). Glob. Environ. Chang. 2004, 14, 105-123.

58. Verburg, P.H.; Schulp, C.J.E.; Witte, N.; Veldkamp, A. Downscaling of land use change scenarios to assess the dynamics of European landscapes. Agric. Ecosyst. Environ. 2006, 114, 39-56.

59. Van Vuuren, D.P.; Lucas, P.L.; Hilderink, H. Downscaling drivers of global environmental change scenarios: Enabling use of the IPCC-SRES scenarios at the national and grid level. Glob. Environ. Chang. 2007, 17, 114-130.

60. Sleeter, B.M.; Sohl, T.L.; Bouchard, M.A.; Reker, R.R.; Soulard, C.E.; Acevedo, W.; Griffith, G.E.; Sleeter, R.R.; Auch, R.F.; Sayler, K.L.; et al. Scenarios of land use and land cover change in the conterminous Unites States: Utilizing the special report on emission scenarios at ecoregional scales. Glob. Environ. Chang. 2012, 22, 896-914.

61. Sleeter, B.M.; Sohl, T.L.; Loveland, T.R.; Auch, R.F.; Acevedo, W.; Drummond, M.A.; Sayler, K.L.; Stehman, S.V. Land-cover change in the conterminous United States from 1973-2000. Glob. Environ. Chang. 2013, 23, 733-748.

62. U.S. Environmental Protection Agency. Level III Ecoregions of the Continental United States, Digital map, scale 1:250,000; U.S. Environmental Protection Agency, National Health and Environmental Effects Research Laboratory: Corvallis, OR, USA, 2013. Available online: ftp://ftp.epa.gov/wed/ecoregions/us/us_eco_13.zip (accessed on 1 April 2014).

63. Sleeter, B.M.; Soulard, C.E.; Wilson, T.S.; Sorenson, D.G. Land-cover trends in the Western United States-1973 to 2000. In Status and Trends of Land Change in the Western United States-1973 to 2000; Professional Paper 1794-A; Sleeter, B.M., Wilson, T.S., Acevedo, W., Eds.; U.S. Geological Survey: Reston, VA, USA, 2012; pp. 3-29. 
64. Omernik, J.M. Ecoregions of the conterminous United States. Ann. Assoc. Am. Geogr. 1987, $77,118-125$.

65. Gallant, A.L.; Loveland, T.R.; Sohl, T.L.; Napton, D. Using a geographic framework for analyzing land cover issues. Environ. Manag. 2004, 34, 89-110.

66. Herger, L.G.; Weiss, A.; Augustine, S.; Hayslip, G. Modeling Fish Distributions in the Pacific Northwest Coast Range Ecoregion Using EMAP Data; U.S. Environmental Protection Agency: Seattle, WA, USA, 2003; pp. 1-48.

67. Mote, P.W.; Parson, E.A.; Hamlet, A.F.; Keeton, W.S.; Lettenmaier, D.; Mantua, N.; Miles, E.L.; Peterson, D.W.; Peterson, D.L.; Slaughter, R.; et al. Preparing for climatic change: The water, salmon, and forests of the Pacific Northwest. Clim. Chang. 2003, 61, 45-88.

68. U.S. Geological Survey GAP. Protected Areas Database of the United States (PAD-US), version 1.3 Combined Feature Class; 2012. Available online: http://gapanalysis.usgs.gov/padus/ (accessed on 13 November 2013).

69. Kerns, B.K.; Shlisky, A.J.; Daniel, C.J. Proceedings of the First Landscape State-and-Transition Simulation Modeling Conference, Portland, OR, USA, 14-16 June 2011; General Technical Report PNW-GTR-869; U.S. Department of Agriculture, Forest Service, Pacific Northwest Research Station: Portland, OR, USA, 2012; p. 215.

70. Daniel, C.J.; Frid, L. Predicting landscape vegetation dynamics using state-and-transition simulation models, In Proceedings of the First Landscape State-and-Transition Simulation Modeling Conference, Portland, OR, USA, 14-16 June 2011; Kerns, B.K., Shlisky, A.J., Daniel, C.J., Eds.; U.S. Department of Agriculture, Forest Service, Pacific Northwest Research Station: Portland, OR, USA, 2012; pp. 5-22.

71. Shlisky, A.J.; Vandendriesche, D. Use of state-and-transition modeling in National Forest planning in the Pacific Northwest, USA. In Proceedings of the First Landscape State-and-Transition Simulation Modeling Conference, Portland, OR, USA, 14-16 June 2011; Kerns, B.K., Shlisky, A.J., Daniel, C.J., Eds.; U.S. Department of Agriculture, Forest Service, Pacific Northwest Research Station: Portland, OR, USA, 2012; pp. 23-42.

72. Publications Using State-and-Transition Simulation Models. Available online: http://wiki.syncrosim.com/index.php?title=Publications (accessed on 25 November 2013).

73. Steele, C.M.; Bestelmeyer, B.T.; Burkett, L.M.; Smith, P.L.; Yanoff, S. Spatially explicit representation of state-and-transition models. Rangeland Ecol. Manag. 2012, 65, 213-222.

74. State-and-Transition Simulation Models, APEX Resource Management Solutions, Ottawa, ON, Canada. Available online: http://www.apexrms.com/projects/stsm (accessed on 10 November 2013).

75. Soulard, C.E.; Acevedo, W. Multi-temporal harmonization of independent land-use/land-cover datasets for the conterminous United States. In Proceedings of the Presentation at the American Geophysical Union, San Francisco, CA, USA, 9-13 December 2013.

76. Anderson, J.R.; Hardy, E.E.; Roach, J.T.; Witmer, R.E. A Land Use and Land Cover Classification Scheme for Use with Remote Sensor Data; Professional Paper 964; U.S. Geological Survey: Reston, VA, USA, 1976; p. 28.

77. Vogelmann, J.E.; Howard, S.M.; Yang, L.; Larson, C.R.; Wylie, B.K.; van Driel, J.N. Completion of the 1990's national land cover data set for the conterminous United States. Photogramm. Eng. Remote Sens. 2001, 67, 650-662. 
78. Homer, C.; Dewitz, J.; Fry, J.; Coan, M.; Hossain, N.; Larson, C.; Herold, N.; McKerrow, A.; VanDriel, J.N.; Wickham, J. Completion of the 2001 national land cover database for the conterminous United States. Photogramm. Eng. Remote Sens. 2007, 73, 337-341.

79. Fry, J.; Xian, G.; Jin, S.; Dewitz, J.; Homer, C.; Yang, L.; Barnes, C.; Herold, N.; Wickham, J.; Completion of the 2006 national land cover database for the conterminous United States. Photogramm. Eng. Remote Sens. 2011, 77, 858-864.

80. Fry, J.A.; Coan, M.J.; Homer, C.G.; Meyer, D.K.; Wickham, J.D. Completion of the National Land Cover Database (NLCD) 1992-2001 Land Cover Change Retrofit Product; Open-File Report 2008-1379; U.S. Geological Survey: Reston, VA, USA, 2009; p. 18.

81. Huang, C.; Goward, S.N.; Masek, J.G.; Thomas, N.; Zhu, Z.; Vogelmann, J.E. An automated approach for reconstructing recent forest disturbance history using dense Landsat time series stacks. Remote Sens. Environ. 2010, 114, 183-198.

82. Roy, D.P.; Ju, J.; Kline, K.; Scaramuzza, P.L.; Kovalskyy, V.; Hansen, M.C.; Loveland, T.R.; Vermote, E.F.; Zhang, C. Web-enabled Landsat data (WELD): Landsat ETM+ composited mosaics of the conterminous United States. Remote Sens. Environ. 2010, 114, 35-49.

83. U.S. Department of Agriculture, National Agricultural Statistics Service (NASS). Cropland Data Layer for the United States; U.S. Department of Agriculture; Washington, DC, USA, 2011.

84. Eidenshink, J.; Schwind, B.; Brewer, K.; Zhu, Z.; Quayle, B.; Howard, S. A project for monitoring trends in burn severity. Fire Ecol. Spec. Issue 2007, 3, 3-21.

85. U.S. Department of Agriculture, Forest Service, U.S. Geological Survey. Forest Cover Types: National Atlas of the United States, Reston, VA, USA, 2002. Available online: http://nationalatlas.gov/metadata/foresti0201.faq.html (accessed on 15 December 2013).

86. Villareal, M.L.; van Riper, C.; Petrakis, R.E. Conflation and aggregation of spatial data improve predictive models for species with limited habitats: A case of the threatened yellow-billed cuckoo in Arizona, USA. Appl. Geogr. 2014, 47, 57-69.

87. Pan, Y.; Chen, J.M.; Birdsey, R.; McCullough, K.; He, L.; Deng, F. Age structure and disturbance legacy of North American forests. Biogeosciences 2011, 8, 715-732.

88. Natural Resources Conservation Service. Soil Survey Geographic (SSURGO) Database; U.S. Department of Agriculture, 2011. Available online: http://soildatamart.nrcs.usda.gov (accessed on 22 November 2013).

89. Sleeter, R.; Gould, M. Geographic Information System Software to Remodel Population Data Using Dasymetric Mapping Methods; U.S. Geological Survey Techniques and Methods 11-C2; U.S. Geological Survey, Reston, VA, USA, 2007; p. 15.

90. Beaumont, L.J.; Duursma, D. Global projections of 21 st century land-use changes in regions adjacent to protected areas. PLoS One 2012, 7, e43714.

91. Daniels, J.M. The Rise and Fall of the Pacific Northwest Log Export Market; General Technical Report, PNW-GTR-624; U.S. Department of Agriculture, Forest Service, Pacific Northwest Research Station: Portland, OR, USA, 2005; p. 84.

92. Klausmeyer, K.R.; Shaw, M.R.; MacKenzie, J.B.; Cameron, D.R. Landscape-scale indicators of biodiversity's vulnerability to climate change. Ecosphere 2011, 2, 1-18. 
93. Hansen, A.J.; Neilson, R.P.; Dale, V.H.; Flather, C.H.; Iverson, L.R.; Currie, D.J.; Shafer, S.; Cook, R.; Bartlein, P.J. Global change in forests: Responses of species, communities, and biomes. BioScience 2001, 51, 765-779.

94. Nelson, D.B.; Abbott, M.B.; Steinman, B.; Polissar, P.J.; Stansell, N.D.; Ortiz, J.D.; Rosenmeier, M.F.; Finney, B.P.; Riedel, J. Drought variability in the Pacific Northwest from a 6000-yr lake sediment record. Proc. Natl. Acad. Sci. USA 2011, doi:10.1073/pnas.1009194108.

95. Carroll, C.; Dunk, J.R.; Moilanen, A. Optimizing resiliency of reserve networks to climate change: Multispecies conservation planning in the Pacific Northwest, USA. Glob. Chang. Biol. 2010, 16, 891-904.

(C) 2014 by the authors; licensee MDPI, Basel, Switzerland. This article is an open access article distributed under the terms and conditions of the Creative Commons Attribution license (http://creativecommons.org/licenses/by/3.0/). 